\title{
磁場が植物に与える影響
}

\author{
柳 沼 光 男
}

日本大学東北高等学校

\section{The Effects of the Magnetic Field on Plants}

\author{
Mitsuo Yaginuma \\ Tohoku High School Attached to Nihon University, \\ 1, Naka-kawara, Tamuramachi, Koriyama 963-11, Japan
}

\begin{abstract}
The growth of the seeds of plants (Cucumis statinus L., Triticum aestivum L. and Raphanus sativus L.) in the soil set up with magnetic field within 30 days are different from the growth of the seeds in the normal soil without magnetic field. In this experiment $1400 \pm 50 \mathrm{G}$ ( $\mathrm{G}=\mathrm{Gauss}$ ) magnetic field and $700 \pm 50 \mathrm{G}$ magnetic field are used.

As a result, it is found that the length of the taproot in $1400 \pm 50 \mathrm{G}$ magnetic field becomes from $40 \%$ to $60 \%$ longer than that of the taproot in the normal soil, but the diameter of taproot becomes $50 \%$ shorter. The length of the taproot in $700 \pm 50 \mathrm{G}$ magnetic field becomes from $15 \%$ to $30 \%$ longer than that of taproot in the normal soil, but the diameter of taproot becomes $33 \%$ shorter.

But after 40 days it is found that the growth of the seeds of plants in the magnetic field and in the normal soil becomes nearly same.

As for the bloom and fructication in case of a cucumbers, it is found that the condition of the bloom and the fructication in the magnetic field becomes worse than that of the bloom and fructication in the normal soil after 90 days from planting seeds. As for the condition of a seed, it is found that a seed in the magnetic field becomes $50 \%$ smaller and softer than a seed in the normal soil.
\end{abstract}

(Received December 28, 1987)

1987 年 12 月 28 日受付

\section{緒言}

電磁気を利用した機器の発達に伴い，それより発生す る磁場が問題となりつつある，磁場が生物にとって，有 益なものか無益なものかは今後多くの研究者により解明 されることと思う。ここではその一環として, 磁場が植 物に与える影響を，コムギ (Triticum aestivum L.), ダイコン (Raphanus sativus L.), キュウリ (Cucumis stativus L.) について実験した結果を報告する.

\section{条件および方法}

自然透過光を利用したハウス栽培で混合土（赤玉土 $66 \%$, 腐葉土 $33 \%$, 化成肥料 $1 \%$ の重量配合土）を用
い，実験種子はタキイ種苗製（99ソ62，58サ62，コムギ は地物）を使い実験した。な拈, 磁場発生源は日立金属 製フェライト磁石 (YBM-2B), 磁場測定器は島津理化 学器機製 (GK-600P) を用いた. 実験磁場は 16 種の磁 場を設定し基礎実験を行ったがその中で効果が顕著であ

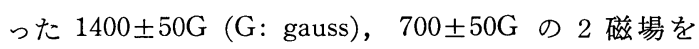
用いた. 磁場は種子および根に与えた. コムギ, ダイコ ンは磁場内植付けによる種子の Fig. 1 に示す配置方向 による生長の報告に用いキュウリは植付け日より 15 日間と 16 日目から 90 日目までの 2 通りにわけ報告し た.

磁場内植付けによる種子の配置方向は Fig. 1 のよう に種子を 4 方向にむけ植付け1), 自然植付けの種子はラ ンダムに植付けた. 


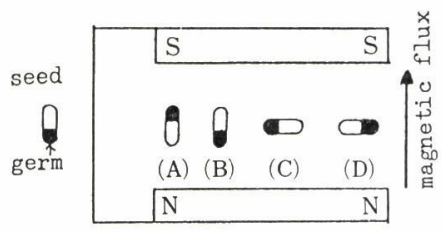

Fig. 1 The direction of the arrangement of planting seeds in the magnetic field.

(A)

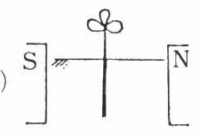

(B)

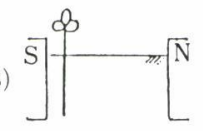

(C)

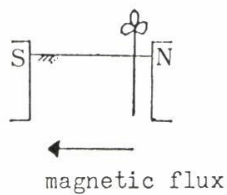

Fig. 2 The arrangement of planting seeds in the magnetic field.
(A) Planting a seed in the center of the magnetic field. Two kinds of $1400 \pm$ $50 \mathrm{G}$ and $700 \pm 50 \mathrm{G}$
(B) Planting a seed toward the south pole of the magnetic field $1400 \pm$ 50G.
(C) Planting a seed toward the north pole of the magnetic field $1400 \pm$ $50 \mathrm{G}$.

磁場内植付けの種子および苗の植付けかたは Fig. 2 のと抢りとした.

\section{実 験 結 果}

Fig. 1 の生長結果は, 植付け日より 10 日後で Photo. 1 のようになった.

Photo. 1 からコムギ，ダイコンの生成は $(\mathrm{A})>(\mathrm{B})>$ (C)=(D) であることがわかる.なお (C), (D) に比べ (B) は $124 \%$ ，(A) は 139\% ほど生成が上まわった.

キュウリの植付け日より 15 日間の生長結果は次のよ らになった。

主根の生長は, Fig. 3 より植付け日から 60 時間まで は自然植付けの生長が上まわる，60１00 時間では磁場 内植付けの生長が上まわる，360 時間（15 日）後の生長 結果は（I ）は（III）の 132\%，(II）は（III）の 121\%， （I）は（II）の $113 \%$ と生長が上まわったが主根の直

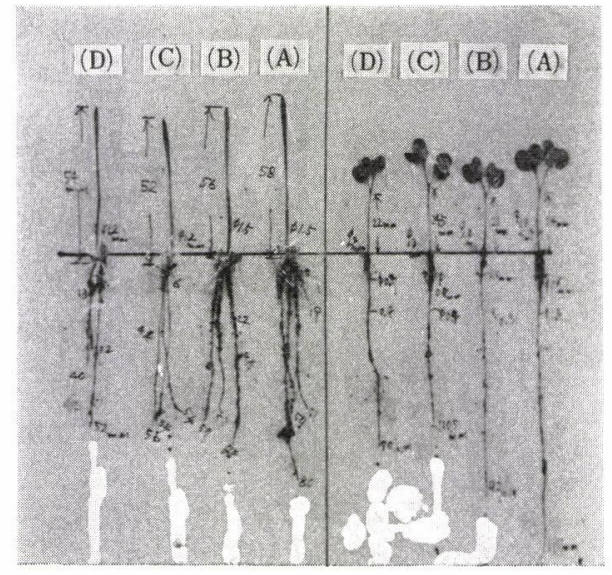

Wheat Japanese radishes

Photo. 1 The growth of planting seeds of wheat and Japanese radishes on different directions in the magnetic field after ten days.

(A) The growth of turning the germs to the south pole.

(B) The growth of turning the germs to the north pole.

(C) The growth of turning the germs to a right angle toward the magnetic flus.

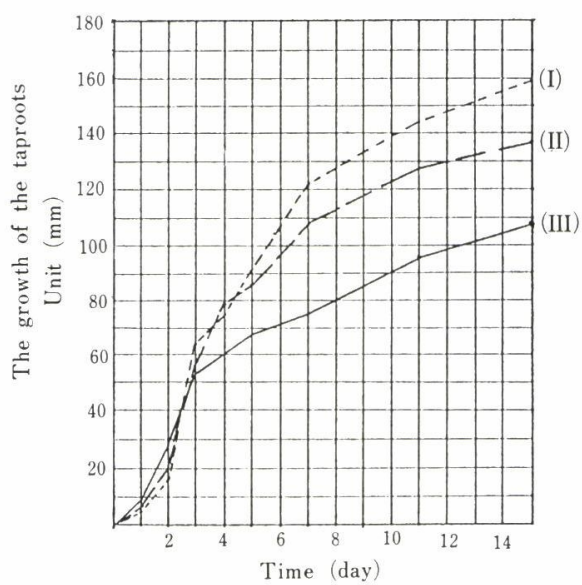

Fig. 3 The growth of the taproots of cucumbers.

( I ) The growth of the taproot of $700 \pm$ $50 \mathrm{G}$

(II) The growth of the taproot of $1400 \pm 500 \mathrm{G}$

(III) The growth of the taproot in the normal soil without magnetic field.

生物環境調節 (Environ. Control in Biol.) 


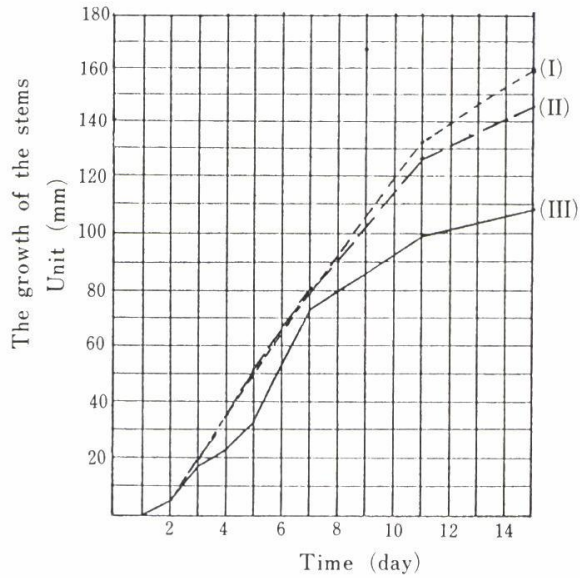

Fig. 4 The growth of the stems of cucumbers.

( I ) The growth of the stem of $700 \pm$ $50 \mathrm{G}$

(II) The growth of the stem of $1400 \pm$ $50 \mathrm{G}$

(III) The growth of the stem in the normal soil without magnetic field.

径（太さ）は自然植付けを 100\%とすると $700 \pm 50 \mathrm{G}$ の磁場内生長では 67\%，1400土50G の磁場内生長では $50 \%$ と細くなった.

茎の生長は Fig. 4 より植付け日から 360 時間後で （I ）は（III）の 132\%,（II）は（III）の $126 \%$, (I ) は（II）の 109\% と上まわり，茎の直径は（I），（II）， （III）共に差は生じなかった.

Photo. 2 は Fig. 1 (A), Fig. 2 (A) による植付け日 から 11 日後の $1400 \pm 50 \mathrm{G}$ の磁場内生長, $700 \pm 50 \mathrm{G}$ の 磁場内生長と自然植付けによる生長の生長結果である. Photo. 2 から $700 \pm 50 \mathrm{G}$ の磁場内生長>1400土50G の磁

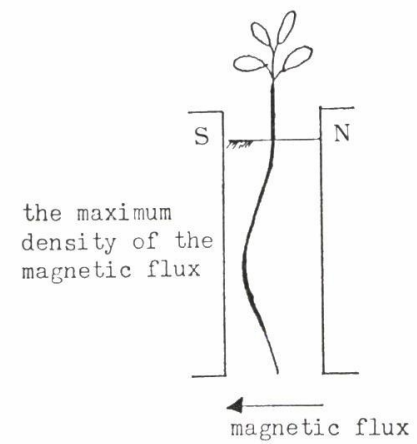

Fig. 5 The condition of growing taproot. The direction of growing taproot becomes arched form as the strength of the magnetic field changes.

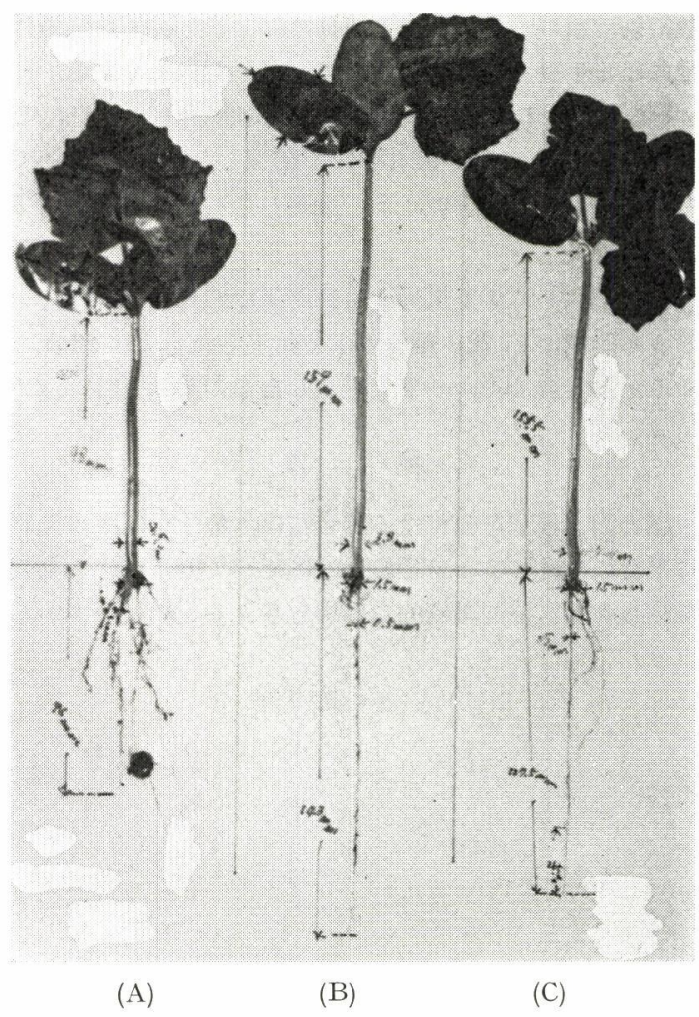

Photo. 2 The growth of planting the seeds of cucumbers after.

(A) The growth of planting a seed in the normal soil without magnetic field. Length of a taproot: 96 $\mathrm{mm}$, length of a stem: $98 \mathrm{~mm}$.

(B) The growth of planting a seed of $700 \pm 50 \mathrm{G}$. Length of a taproot: 143, length of a stem: 159.

(C) The growth of planting a seed of $1400 \pm 50 \mathrm{G}$. Length of a taproot: 127, length of a stem: 155 .

場内生長>自然植付けによる生長であることがわかる.

キュウリの植付け日より 16 日目から90日目までの生 長結果は次のようになった。

$1400 \pm 50 \mathrm{G}$ の磁場内生長では, 植付け種子の総数の 85\% が Fig. 5 のように主根が弓になりに湾曲した.

Fig. 2 (A) による果実の生長結果は, $1400 \pm 50 \mathrm{G}$ の 磁場内生長では開花数 176 花, そのらち雌花は 26 花, 雌花の中で結実したものは 12 花であった. $700 \pm 50 \mathrm{G} の$ 磁場内生長では開花数 144 花, そのうち雌花は 39 花, 雌花の中で結実したものは 22 花であった。自然植付け による生長の開花数は 216 花, そのらち雌花は 37 花, 雌花の中で結実したものは 29 花であった。な特，開花 
数, 結実数の調查は磁場内植付けによる生長, 自然植付 けによる生長共に各 1 本ずつで測定した結果である.

Fig. 2 (B) による果実の生長結果は開花数 184 花, そ のうち雌花は 24 花, 雌花の中で結実したものは 18 花で あったが果実長 $100 \mathrm{~mm}$ まで生長したものは 2 花だけで あった.

Fig. 2 (C) による果実の生長結果は開花数 121 花，そ のうち雌花は 27 花, 雌花の中で結実したものは 23 花て あるが果実長 $100 \mathrm{~mm}$ まで生長したものが 22 花あった。

\section{検討}

磁場内へ種子を植付ける場合には, 種子を磁束の流れ に平行に植付けると自然植付けに比べて効率のよい生長 が見られる．根に継続的に磁場を与えると植付け日から
30 日以内であれば, コムギ, ダイコン, キュウリの 3 種類の主根の生長は上記 3 種類を自然に植付け生長させ たときの主根の生長に比べて平均で $125 \%$ 前, 後生長 が上まわる. 磁場が根に作用しているかどらかの判断 は, 磁場の強, 弱で根がぞの方向へ湾曲するかを調べれ ば推定できる．結実の状態から考虑すると磁場内で植物 を生長させるときは，収穫を目的とする栽培には適さな いように思われる。

\section{文献}

1）加藤良一・金子忠男 - 高辻正基 - 鎌田 博. 日本生 物環境調節学会 25 大会, $62-8-28,29$, p. 44-19, 図 4

2）前田担. 1985. 生物は磁気を感じるか, 講談社, 東京. 